Pikó Bettina* - Kopp Mária

\title{
A MAGATARTÁSORVOSLÁSI SZAKCSOPORT TUDOMÁNYOS KUTATÁSI JÖVÔKÉPE
}

2004. szeptember 28-án megalakult a Klinikai Pszichológia Szakkollégium Magatartásorvoslási Szakcsoportja. Elnöke: Prof. Dr. Kopp Mária. Tagjai: Dr. Barabás Katalin, Dr. Kállai János, Dr. Molnár Péter, Dr. Pék Győző, Dr. Pikó Bettina, Dr. Purebl György, Dr. Varga József.

A magatartásorvoslás definícióját az 1977-es Yale konferencián a következóképpen fogalmazták meg: interdiszciplináris terület, amelynek célja, hogy a magatartástudomány és a biomedicina tudáskincsét és módszertanát integrált módon alkalmazza az egészséggel és betegséggel kapcsolatos problémák során a prevenció, a diagnózis, a gyógyítás és a rehabilitáció valamennyi területén.

Ennek következtében a magatartásorvoslásnak szinte valamennyi területtel és specializációval kapcsolatban kell állnia, hiszen olyan szemléletet képvisel, amely elôsegíti a holisztikus, biopszichoszociális orvoslás modern kori megvalósulását.

Ahhoz, hogy ez a gyakorlatban megvalósulhasson, empirikusan igazolt kutatási eredményekre és ezek hatékony alkalmazására van szükség. A modern társadalom legfontosabb kihívása, hogy a megváltozott világszemlélet, az individualizált társadalomkép, a felgyorsult életritmus és a fogyasztói társadalom érték- és normarendszere fokozott adaptációt igényel az egyének és közösségek részéról. Ennek a megnövekedett adaptációs igénynek a modern orvoslás csak akkor tud megfelelni, ha egyidejúleg figyelembe veszi, azaz integrálja a természettudományos és a társadalomtudományos szemléletet és ezek tudományos eredményeit. Ez a fajta híd funkció elsósorban a magatartásorvoslás sajátossága, amely tehát - mint speciális orvostudományi terület - lehetôvé teszi az integrációt, éppen azáltal, hogy egyaránt magában foglalja mindkét paradigmát.

A magatartásorvoslás kutatási területeinek besorolásához a fenti definíciót vettük alapul. A kutatásoknak azonban valamennyi részterületen követniük kell a komplex látásmódot, a biopszichoszociális szemlélet

\footnotetext{
* Levelezó szerzó:

Dr. Pikó Bettina, SZTE Pszichiátriai Klinika, Magatartástudományi Csoport

6722 Szeged, Szentháromság u. 5.

E-mail: piko@nepsy.szote.u-szeged.hu
} 
hatékony megvalósulását. A meghatározásnak megfelelően a magatartásorvoslás tudományos részterületeit az alábbiakban ismertetjük.

\section{PREVENTÍV MAGATARTÁSORVOSLÁS}

A 20. században - különösen annak második felétól - fokozatosan elótérbe került a prevenció, a betegségek megelôzése és az egészség fejlesztése, a tudományos haladás ugyanis nyilvánvalóvá tette a betegségek megelózhetőségét. Korábban, amíg a természettudományos fejlődés vívmányai nem tették lehetôvé a betegség tüneteinek korai felismerését és a hatékony megelózó módszerek - így például a védőoltások - kifejlesztését, a prevenciónak alig voltak meg a lehetôségei. A megelôzés segítségével valósíthatjuk meg az orvoslás azon alapelveit, hogy ne ártsunk, és igyekezzünk a betegeket megkímélni a szenvedéstól. Az idóben észrevett betegségek bizonyos típusai ezenkívül költséghatékonyabban kezelhetók. A betegségmegelózéssel párhuzamosan elótérbe került az egészségfejlesztés is, amelynek legfontosabb záloga az egészség feletti kontroll és az egészséges személyiségfejlődés. A prevenció tehát sok szállal kötődik a magatartásorvoslás elméleti alapjaihoz. A szakcsoport által javasolt, kiemelt kutatási területek az alábbiak:

1. A káros szenvedélyek (dohányzás, alkoholfogyasztás, illegális drogfogyasztás) komplex, magatartásorvoslási vizsgálata.

2. Kiemelt népbetegségek (pl. reumatikus kórképek, allergiás megbetegedések, szív- és érrendszeri, daganatos betegségek stb.) megelózésének komplex, magatartásorvoslási lehetôségei.

3. A mentálhigiéné magatartásorvoslási alapjainak kidolgozása, a mentális zavarok emelkedéséhez hozzájáruló rizikófaktorok komplex, biopszichoszociális összefüggéseinek elemzése.

4. A kockázati magatartásformák és mentális zavarok rizikó- és protektív szemléletú elemzése.

5. Egyenlőtlenségek az egészségi állapotban, a sérülékeny csoportok azonosítása, az esélyegyenlőség lehetôségeinek kutatása.

6. Speciális lakossági csoportok, szubkultúrák, demográfiai rétegek prevenciós részvételét befolyásoló tényezők komplex rendszerének kutatása.

7. A nemek szerepe az egészségfejlesztésben, a család szerepe a betegségmegelózésében.

8. Fiatalok komplex egészségfejlesztésének kutatása. 


\section{KLINIKAI MAGATARTÁSORVOSLÁS}

A magatartásorvoslás hagyományosan a klinikum területén fejtette ki hatását mint pszichoszomatikus orvoslás. Magyarországon is elsósorban e területen vannak a magatartásorvoslásnak hagyományai, hiszen a pszichoszomatikus orvoslás megalapítói magyar tudósok voltak (Semmelweis Ignác, Franz Alexander, Bálint Mihály, Ferenczi Sándor, Selye János). A klinikai magatartásorvoslás tehát ennek megfelelóen erósen terápiaorientált, de míg a pszichoszomatikus orvoslás elsósorban pszichoanalitikus hagyományokra épült, a magatartásorvoslás inkább a kognitív és magatartáskontroll alapú terápiákat helyezi előtérbe, magában foglalva azonban a pszichoszomatikus/pszichoanalitikus szemléletet is. A klinikai magatartásorvoslás a terápián túlmenóen kiterjed a diagnózis komplexitásának megvalósítására is, azaz a betegségek kialakulásában szerepet játszó pszichikai, társas/társadalmi és kulturális szempontok felderítésére is. Emellett pedig a klinikum területén a kutatási területeknek is híven kell követniük a magatartástudományok és a biomedicina integrációját tükrözô kulturális orvoslás, orvos-beteg kommunikáció, orvosi etika, orvosi pszichológia és szociológia tudományos szempontjait.

A fentieknek megfelelóen a klinikai magatartásorvoslás három fó pillére:

- a terápiaorientált magatartásorvoslás, és az ezt elôsegító terápiás módszerek evidencia alapú kutatása;

- a diagnózisorientált magatartásorvoslás, a betegségek egyéni kialakulásában és lefolyásában szerepet játszó tényezók komplex kutatása;

- a kapcsolat-és intézményorientált magatartásorvoslás, amely az orvosbeteg kapcsolat és az orvoslás intézményesített rendszerének kutatását jelenti.

A szakcsoport által javasolt, kiemelt kutatási területek az alábbiak:

1. A betegségfolyamatok komplex, biopszichoszociális elmélete.

2. Pszichoszomatikus, illetve biopszichoszociális orvoslás konkrét betegségek (betegségcsoportok) esetében.

3. A betegségekkel történó megbirkózás (coping) folyamatának kutatása.

4. A betegségek kialakulását, illetve lefolyását befolyásoló protektív tényezók elemzése (pl. társas támogatás, vallásosság, adaptív coping technikák, énhatékonyság stb.).

5. A betegségek befolyása az életminőségre.

6. A pszichoterápia és a biológiai terápiák komplex tanulmányozása, a pszichoterápiák pszichofiziológiai vizsgálata. 
7. Stressz és betegségfolyamatok komplex elemzése.

8. Terminális betegek ellátásának vizsgálata.

9. Az orvos-beteg kommunikáció hatékonyságát befolyásoló tényezók vizsgálata.

10.Fájdalommagatartás, a fájdalom komplex értelmezése.

11.Burnout (kiégés) jelensége az egészségügyben.

\section{REHABILITÁCIÓS MAGATARTÁSORVOSLÁS}

Az idôs lakosság számarányának folyamatos emelkedésével, a krónikus betegségek gyakoriságának növekedésével és az életminóség elótérbe kerülésével fokozatosan egyre nagyobb figyelem irányul a rehabilitációra. A népbetegségek jelentôs része hosszú távú gondozást igényel, amelynek megvalósulása közben módosul az orvos-beteg kapcsolat, és a betegszerep is. A betegek állapotának rosszabbodását megelózendó, fokozott figyelmet kell fordítani a pszichoszociális szempontokra is. A rehabilitációs magatartásorvoslás területén végzett kutatásoknak ezért elsósorban a rehabilitáció komplex, biopszichoszociális jellegzetességeit kell hangsúlyozni.

A szakcsoport által javasolt, kiemelt kutatási területek az alábbiak:

1. Krónikus betegségek hatása az életminôségre.

2. Geriátriai magatartásorvoslás, az idôsek életminóségét befolyásoló tényezók magatartástudományi elemzése.

3. A mozgásszervi rehabilitáció pszichoszociális szempontjai, és komplex rendszerének kutatása.

4. A magatartásorvoslás lehetôségei a pszichiátriai és addiktológiai rehabilitáció területén.

5. Kardiovaszkuláris rehabilitáció komplex elemzése, várható hatások az életminôség vonatkozásában.

Összefoglalva: a magatartásorvoslás területén végzendô, általunk javasolt kutatások eredményei közvetlenül hasznosíthatók a prevenció, a klinikum és a rehabilitáció területén, azaz a kutatási eredmények hozzájárulhatnak az orvoslás hatékonyságának emeléséhez, a betegelégedettség javításához és az egészségügy humánusabb szervezéséhez. 